\title{
RATING CONSUMPTION OF CONFECTIONERY PRODUCTS BY PERSONS TRAINING AMATEUR
}

\author{
OCENA SPOŻYCIA WYROBÓW CUKIERNICZYCH \\ PRZEZ OSOBY TRENUJĄCE AMATORSKO
}

Chair of Vascular and Internal Diseases, Department of Gastroenterological Nursing, Faculty of Health Sciences, The Ludwik Rydygier Collegium Medicum in Bydgoszcz, Nicolaus Copernicus University in Toruń

\section{S u m mary}

Human health is not defined by the absence of diseases but as a general welfare of a person that allows life full of vigour, enthusiastic performance of daily duties, fulfilling dreams and coping with different environmental conditions.

Proper lifestyle should be determined by application of the principles of proper nutrition combined with regular physical activity. The human body works better when it is subjected to daily physical activity and a proper diet.

Our social norms, i.e. majority of people lead sedentary lifestyle, lead to improper expression of our genes that results in the development of chronic diseases, referred to as diseases of civilization.

The aim of the study was to evaluate the consumption of confectionery by people exercising in the Fit-Max fitness centre in Bydgoszcz as well as respondents' motivation to undertake physical activity. The study showed that those exercising in Fit-Max were characterized by high physical activity:they attend classes seven days a week on average and devote from 1 to 3 hours per day for a training session selecting different forms of activity. Their main objective is weight loss, improved muscle strength, fitness and better well-being.

Respondents have a wide knowledge of the principles of nutrition; however, they do not follow them in everyday life. Only a small number of respondents use restrictive diets. Although BMI of some of the surveyed indicates overweight and obesity according to the subjective assessment, there are respondents who claim that their body build is within the norm.

The respondents admit to regular and frequent consumption of confectionery products due to a number of various reasons, despite the performance of physical activity.

Although most respondents did not feel remorse after consumption of sweets, they have reduced the amount of food assortment in favour of increased physical activity due to the increase in body weight
Zdrowie człowieka nie jest określane przez brak jakichkolwiek chorób, lecz jako ogólny dobrostan osoby, który umożliwia życie w pełni wigoru, spełniając $\mathrm{z}$ entuzjazmem codzienne obowiązki, realizowanie marzeń a także radzenie sobie $\mathrm{z}$ różnymi warunkami środowiska. Właściwy styl życia powinien być determinowany przez stosowanie zasad prawidłowego żywienia połączonych z regularną aktywnością fizyczną. Ciało ludzkie lepiej funkcjonuje, jeśli jest poddawane codziennej aktywności fizycznej i odpowiedniej diecie. Nasze normy społeczne, gdzie większość prowadzi siedzący tryb życia, prowadzi do niewłaściwej ekspresji naszych genów, co powoduje rozwój chronicznych chorób, określanych jako cywilizacyjne.

Celem pracy była ocena spożycia wyrobów cukierniczych przez osoby ćwiczące w klubie Fit-Max w Bydgoszczy, a także ocena motywacji badanych do podjęcia aktywności fizycznej. 
Badanie zostało przeprowadzone za pomocą anonimowej ankiety wśród 100 osób pełnoletnich w różnym przedziale wiekowym, uczęszczających do klubu Fit-Max w Bydgoszczy, określających się dodatkowo jako zdrowe. Badanie to nie dotyczyło osób nieletnich i kobiet w ciąży.

W pracy wykazano, iż osoby ćwiczące w klubie Fit-Max cechują się wysoką aktywnością fizyczną. Uczęszczają na ćwiczenia średnio 7 dni w tygodniu i poświęcają jednorazowo na trening od 1 do 3 godzin dziennie, wybierając różne formy aktywności. Głównym celem ćwiczących jest spadek masy ciała, poprawa siły mięśni, kondycji oraz lepsze samopoczucie.

Respondenci wykazują dużą znajomość zasad prawidłowego żywienia . Jednak ta wiedza nie przekłada się

Key words: physical activity, diet, consumption of sweets

Stowa kluczowe: aktywność fizyczna, żywienie, produkty cukiernicze

Proper diet of physically active people is aimed at sufficient provision of food containing energy, nutrition, vitamins and minerals in appropriate portions. Maintaining adequate supply of carbohydrates, proteins and fats, vitamins and minerals will ensure the maintenance of health [1]. The frequency, the amount and timing of food we eat are very important [2]. The number of meals for people who exercise should be between 5 and 6 per day. Those meals should be rich in energy and, at the same time, small in volume to insure the supply of daily energy dose. 2 to 3-hour intervals between each meal aid in keeping the correct glucose blood concentration. All-training nutrition is also very important. Approximately 2 hours before training light meal rich in complex carbohydrates should be consumed. Starting exercises with a full stomach is very unfavourable. Each training session should be supplemented by providing simple carbohydrates to rebuild muscle glycogen. Protein consumption will prevent the start of catabolic processes $[3,4,5]$.

Carbohydrates are the main source of energy for the human body. They provide energy in the form of glucose due to digestion and absorption into tissues inside which they oxidize to $\mathrm{CO} 2$ and $\mathrm{H} 2 \mathrm{O}$. In daily nutrition they provide $60 \%$ of overall energy. 1 gram of carbohydrates provides 4 kilocalories (16.7 kJ). Besides energy, carbohydrates are vital for oxidizing fatty acids. In case of carbohydrate deficiency in the diet (less than 100g/day) incomplete oxidation of fatty acids occurs, which results in ketones production acidifying our body. What is more, carbohydrates are a part of glucogenic amino acid synthesis (amongst na ich przestrzeganie w życiu codziennym. Tylko niewielka część badanych stosuje diety ograniczające. Pomimo że BMI u części badanych wskazuje nadwagę i otyłość, według subiektywnej oceny znaczna część respondentów uważa, iz prezentowane przez nich sylwetki mieszczą się w przedziale przyjętych norm.

Respondenci przyznają się do regularnego i częstego spożywania wyrobów cukierniczych pomimo podjęcia aktywności fizycznej. Badani podawali wiele powodów, dla których sięgają po produkty cukiernicze.

Mimo iż większość respondentów nie odczuwa wyrzutów sumienia po konsumpcji słodyczy, zmniejszyli oni ilości spożywanego asortymentu na rzecz wzmożonej aktywności fizycznej z powodu wzrostu masy ciała. others glutamic and aspartic acid, histidine, alanine or glycine).

As the Polish population study indicates, the amount of overall consumed carbohydrates is decreasing year by year in relation to nutrition and health experts. Lower consumption of carbohydrates products is resulting in the increased amount of the fat delivered in the diet. Despite the downward trend of carbohydrates supply, not only the quantity but also kind of the supplied carbohydrates products is important. Over the several recent years excess share of sucrose in the diet has been witnessed. Sucrose should not supply more than $10 \%$ of overall energy. The surplus of sucrose may cause Insulin-Dependent Diabetes Mellitus (IDDM), overweight and obesity, and dental problems. Along with fibre deficiency in the diet, it may cause digestive processes disorders, which in turn can result in oesophageal, gastric and intestinal cancer $[6,7]$. Consuming too many sugars and sweets increases the feeling of satiety which can decrease the supply for other foods significant from the point of view of health. Limitation of sugar, honey and confectionery products consumption to the minimum level is proposed. Maximum supply values of that food group should not exceed the range between 50 to $85 \mathrm{~g}$ ( $>10 \%$ of overall energy), depending on one's type of work performed and lifestyle [8].

\section{EFFECT OF PHYSICAL ACTIVITY ON HUMAN HEALTH}

Nowadays, human health is not defined by the absence of diseases but as a general welfare of a person that allows life full of vigour, enthusiastic performance 
of daily duties, fulfilling dreams and coping with different environmental conditions. Sedentary lifestyle leads to improper expression of our genes that results in the development of chronic diseases, referred to as diseases of civilization. This include most of all Coronary Artery Disease (CAD), diabetes, obesity and hypertension (HTN). Physical exercise has a direct impact on metabolism which helps to maintain the balance between the energy provided from the food and the energy used by the body. Physical exercise helps to distribute the elements of consumed food. The most positive effects of regular practicing of sport are: increasing of respiratory function, improving physical fitness, reducing the risk of cardiovascular disease and metabolic disorders (obesity and diabetes) as well as reduced fatigue experiencing in daily life while doing chores. Moreover, physical exercise strengthens the motor system, prevents universally known degenerative changes of the spine. The increase of muscle strength enhances functioning and relieves skeleton during the performance of regular activities. Improvement of flexibility and agility of the limbs decreases the risk of injuries and fractures. Practicing any recreational activity for a long period of life mobilizes the body to stay in better shape in subsequent years. That is why regular physical activity along with proper nutrition is significant [9, 10]. Confectionery products commonly referred to as sweets are a wide range of processed products. They are well-known and much preferred products, consumed despite they are not necessity products. Confectionery products are divided into following groups: candies, chocolate, candy bars, eastern products (halvah). They are characterised by high energy content due to high fat and sucrose (sugar) content. Sucrose content in sugar and hard candies reaches $99 \%$. Chocolate, chocolate substitutes products, halvah and some of the baker's wares apart from their high sugar content, possess significant fat content. Some of them also have small amounts of protein in its composition (halvah up to $20 \%$ of protein). Caloric value of confectionery products is high and falls in the range from 300 to $600 \mathrm{kcal} / \mathrm{g}$ $(1257-2514 \mathrm{~kJ} / \mathrm{g})$. The nutritional value of sweets varies and depends on the kind of confectionery product $[6,11,12]$. Apart from white sugar and sweets, honey is also in the confectionery products group. Not only it contains fructose and glucose but also pollen, minerals and enzymes. Honey is added during the manufacture of confectionery products as well as sugar.

The aim of this study was: 1 to evaluate the consumption of confectionery by people exercising in the Fit-Max centre in Bydgoszcz; 2. Respondents' motivation to undertake physical activity; 3 Has respondents attitude towards healthy diet changed after taking up regular exercises?

Methodology of the study. A survey was conducted among the Fit-Max club members in a form of questionnaire. The questionnaire was anonymous, noninvasive and required the consent of its participants for attendance. Nutrition evaluation was carried out based additionally on calculations of Body Mass Index BMI. The survey was carried out on a group of 100 adult people of all ages, attending Fit-Max club in Bydgoszcz, qualifying themselves as healthy. Minors and pregnant women were excluded from the study. Result analysis and all needed calculations were carried out in Microsoft Excell. The first part of the survey contained questions about the sex, age and current body mass and height. Furthermore, it contained questions about marital status, permanent residence, education and occupation. The second part of the survey contained question concerning frequency of physical activity undertaken within a week, its type, aim and the average time of a single session of exercises. Moreover, it contained questions regarding the knowledge of healthy nutrition rules and their application, diet and subjective evaluation of respondents' way of nutrition. The third part contained a table of the frequency of consumption of selected confectionery products (on a scale from a daily consumption to an incomplete consumption of the selected product). Respondents answered about their reasons for consuming confectionery products, their subjective opinions about the influence of sweets on human health, well-being and the achievement of the objectives connected with taking up physical activity. Respondents also mentioned products, which in their opinion they consumed the most frequently and find favourite. They were asked about noticeable changes in their body mass caused by consuming sweets and if the increase of their physical activity contributed to consume less confectionery products.

\section{RESULTS}

Characteristics of the surveyed group. Data analysis suggested that a hundred people took part in the 
survey, 50 women and 50 men. They have been regular users of Fit-Max club in Bydgoszcz. Surveyed women were aged between 18 and 56 years, Among men, the youngest participant was 18 years old and the oldest was 45 years old. Average female respondent's age was 29, whereas male respondent's age was 26 .

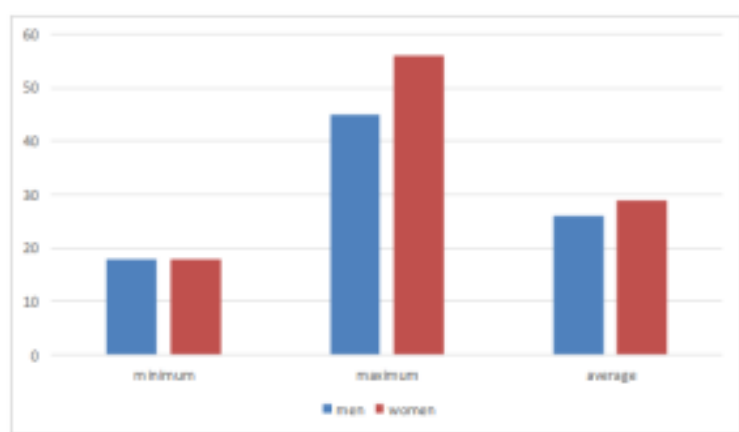

Fig. 1. Age of the study population

Average women respondent's height was $166 \mathrm{~cm}$ and men $180 \mathrm{~cm}$. Average female respondent's body mass was $62 \mathrm{~kg}$ and male was $66 \mathrm{~kg}$. Due to the data on height and body mass of women, BMI was calculated $(\mathrm{kg} / \mathrm{cm} 2)$. The lowest values of women's $\mathrm{BMI}=17.5$, which according to WHO indicates underweight. lowest values of men's $\mathrm{BMI}=19.0$. The highest values of women's BMI was 36 and for men 34.2, which indicates obesity. Average BMI among women was 22.49 and among men was 20.37. Table 1 .

Tab. 1. Anthropometric characteristics of the study group

\begin{tabular}{|l|l|l|l|l|l|l|}
\hline Feature & \multicolumn{2}{|c|}{$\min$} & \multicolumn{2}{c|}{$\max$} & \multicolumn{2}{c|}{ mean } \\
\hline Gender & $\mathrm{W}$ & $\mathrm{M}$ & $\mathrm{W}$ & $\mathrm{M}$ & $\mathrm{W}$ & $\mathrm{M}$ \\
\hline height & 156 & 170 & 175 & 194 & 166 & 180 \\
\hline $\begin{array}{l}\text { Body } \\
\text { mass(kg) }\end{array}$ & 50 & 65 & 98 & 105 & 62 & 66 \\
\hline BMI & 17.5 & 19.0 & 36 & 34.2 & 22.49 & 20.37 \\
\hline
\end{tabular}

The largest proportion of female $(82 \%)$ and male respondents $(70 \%)$ lived in the city with population over 100000 - Bydgoszcz, only $2 \%$ of female respondents and $5 \%$ of males are people from cities with population under 25000 . The remaining respondents dwell in the country $(8 \%$ women and men). Over $3 / 4$ of males and half of females were single. 14 men (28\%) and $8(16 \%)$ women were married, the rest declared being in informal relationships 1 (4\% of men and $8 \%$ of women). $74 \%$ of respondents were professionally active, $24 \%$ of women and $20 \%$ of men were students, $4 \%$ of men were unemployed. Only one man and one women were unemployed. Respondents took up physical activity with different frequency during the week. Average number of hours reserved for training per week for women was (6.67) and for men (7.3). Women trained $6(22 \%)$ to $8(16 \%)$ hours per week. Men estimated their training hours similarly, most of them (26\%) trained 6 hours, whereas $14 \%$ of respondents declared 8 and 10 hours for training per week.

Survey participants were also asked for the amount of hours dedicated at a time for a visit in the Fit-Max club. Most women used club's services from 1 hour (34\%) to 1.5 hours (30\%) per day. Among men it was a period from 1.5 hours $(36 \%)$ to 2 hours $(30 \%)$.

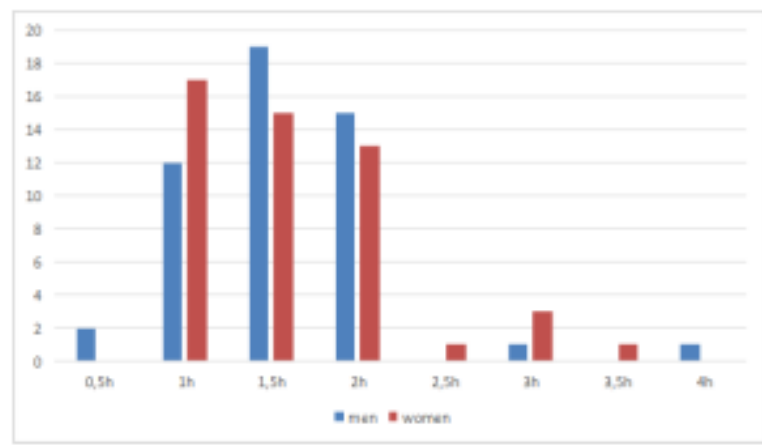

Fig. 2. How much time is spent on exercises during the day average?

In the next section of the survey respondents were asked for the aim of their exercises. Women most frequently aimed at a weight loss (22\%), desire to obtain better looks by improving the figure or fitness $(16 \%)$. Among men over a half declared that the main aim of their training was enhancing strength and/or endurance $(28 \%)$, as well as weight loss $(20 \%)$ or a better shape $(18 \%)$.

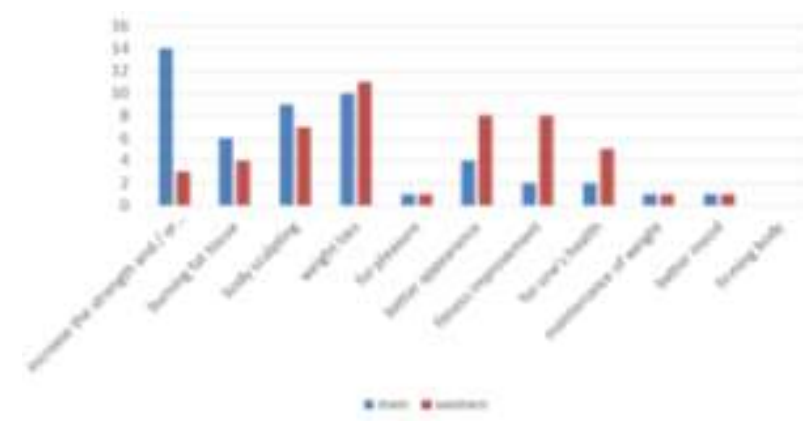

Fig. 3. What is the purpose of your exercise?

Next question concerned noticeable changes in the body since taking up physical activity. Women most frequently indicated loss of fat $(34 \%)$, mood improvement (16\%), better shape and energy improvement during the day (12\%). Men assessed their training as positive due to muscle improvement (36\%) 
better shape and loss of fat $(24 \%)$. Data is presented in figure 4 .

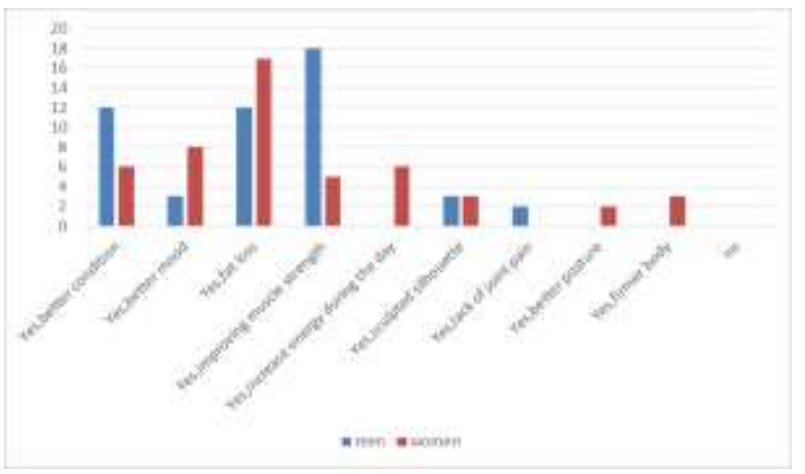

Fig. 4. If you notice changes in your body since starting the exercises?

In the question regarding the knowledge of healthy nutrition rules, both sexes most frequently indicated regular meals every 3 hours, 5 small portions ( $32 \%$ of women and $20 \%$ of men), additionally drinking lots of fluids (16\% of women). However, $5 \%$ of women and one in four men $(26 \%)$ does not know the healthy nutrition rules.

Overwhelming majority of respondents did not apply any restrictive diet ( $82 \%$ of women and $70 \%$ of men). $8 \%$ of women had a diet plan composed by a dietician, $6 \%$ by a trainer, whereas $12 \%$ of men declared using high protein diet or nutritional plan from their trainer (14\%).

Respondents positively assessed their body mass, circumstantiating that it ranges between the norms ( $84 \%$ of women and $68 \%$ of man) Only $4 \%$ of male and female respondents claimed that they had too low weight, $12 \%$ of women and $28 \%$ of men are above the standard weight. When it comes to the question about the acceptable norm of consumed sugar and fat per day, only 3 women answered correctly, giving the amount of 3 grams and 10 grams per day of admissible amount of sucrose. Unfortunately, none of the men answered correctly. When it comes to admissible amount of fat consumed per day all the respondent showed lack of knowledge. Almost all of the respondents admitted to confectionery products consumption. ( $92 \%$ women and $88 \%$ of men).

In the next question, respondents were able to list their favourite confectionery products. Most frequent product among women was a chocolate bar (12\%), candies, chocolate and ice cream (10\%). Man most frequently consumed candy bars (20\%) buns (20\%) chocolate and cakes (16\%), and ice creams (14\%).
Time of the day when the confectionery product were consumed was also analyzed. Most of the respondents ( $20 \%$ of women) consumed sweets before dinner, and men after dinner $(22 \%)$. Some of the respondents also consumed sweets after dinner (12\% of women) for teatime $(16 \%$ of women and $14 \%$ of men) or before training (14\% of men). One out of ten women admitted to eating sweets for breakfast and at night. Some of men admitted to eating confectionery products after breakfast $(8 \%)$, before dinner $(12 \%)$ and after their training (10\%).

To the question: 'Why do you eat confectionery products' a wide range of answers was given. Women frequently answered: They are delicious (24\%), their mood improves after consumption of sweets $(12 \%)$ or they just like eating them (12\%). Men often eat sweets due to the energy increase after their consumption (16\%), for tasting (14\%) or they claim to like sweets (14\%). The survey also had a question about the body weight changes due to confectionery products consumption. Almost half of men $(48 \%)$ and a half of women $(50 \%)$ noticed the increase of weight after sweets' consumption. In case of women the weight increase fluctuated from $1 \mathrm{~kg}(14 \%)$ to $3 \mathrm{~kg}(8 \%)$. Upper limits reached $10 \mathrm{~kg}$ and $15 \mathrm{~kg}(10 \%)$. Men weight most frequently increased in the range from $1 \mathrm{~kg}$ to $3 \mathrm{~kg}(10 \%)$. There were also values of $6 \mathrm{~kg}(6 \%), 10$ $\mathrm{kg}$ and $16 \mathrm{~kg}(2 \%)$. After consuming sweets most of the respondents $(50 \%)$ did not feel any remorse after consumption of sweets, whereas a significant number of respondents, $68 \%$ of women and $54 \%$ of men had taken up regular exercises to "burn" redundant calories consumed with the sweets. Consumption of confectionery products had also a direct effect on taking up physical activity by both sexes.

\section{DISCUSSION}

The way of dieting is one of the most important elements of lifestyle which influences health and conditions for the correct functioning of human body. Rapid pace of life, stress and low physical activity are some of the reasons which can cause irregular way of life and lead to irrational dietary. That kind of behaviour increases the risk of overweight and obesity development and many other civilisation illnesses such as hypertension, dental caries, diabetes and atherosclerosis in the future $[13,14,15]$. Proper choice of class of foods and moderate, regular physical activity are the element of prevention of diseases of 
civilization developing on the grounds of obesity $[16,17]$. Over the last years all over the world as well as in Poland, functional food market has intensively developed $[18,19]$. Sweets are the products especially popular among the majority of the population. Those products are highly processed in comparison with the raw commodities [20]. Polish market offers a wide range of confectionery, what in turn directly influences nutrition problem. Despite the calls from doctors and dieticians confectionery consumption has been growing constantly for the last years [21]. Confectionery products are the main source of energy for our body [22, 23]. Apart from sugar, they contain other nutrients and energy components such as: fats, flour and additives. Within the range of confectionery there are products high in fat content, over $30 \%$ with the calorific value of 300-600 kcal/g. Apart from that, products made from cocoa beans may include small amounts of minerals such as magnesium, calcium or iron and vitamin B [6, 24]. Apart from their energy value, confectionery products are very popular among consumers due to their sensory qualities $[12,25,26]$. Numerous epidemiological studies have shown positive results of physical activity. Except for weight loss, physical activity improves circulatory system as well as osteo-articular, muscle and respiratory system, glucose metabolism and blood lipid profile. Psychological aspect is also important. Exercising regularly keeps the high level of endorphins which transforms into mood improvement, decreases the risk of depression and improves sleeping. Systematic activity is important at any time of life [27]. Practicing sports the whole life, from early years positively influences the quality of life in old age [28]. The issue of consuming confectionery by physically active people is not included in the medical literature. Author's study enabled gathering data concerning dieting, selected physical activities, frequency of confectionery consumption and reasons for their consumption among the people training in Fit-Max centre in Bydgoszcz. Average BMI value obtained in the study group of men was 20.37. This result is slightly lower than the one provided by Adamczyk et al. in the study carried out within a group of men attending gyms in Warsaw. Authors noted average BMI between 25.02 and 27.2 depending on the period they trained. The study results clearly state that the selected group of men is within the norm of healthy body weight. In the thesis and the study carried out by Adamczyk et al., men attending the gym mostly performed strength training or combined it with cardio training (over $30 \%$ of men). Main reasons for taking up physical activity by men in this study was to increase strength and endurance (28\%), weight loss $(20 \%)$ or shape improvement $(18 \%)$. The result in the study by Adamczyk et al. was similar and the main reason for taking up physical activity was the improvement of appearance and well-being. [29] In the case of women average BMI was 22.49, which places respondents within norms. This result is close to the study by Gogojewicz et al., which was carried out on women training in a fitness club in Poznań (BMI 23.8). [30] Women included in this study combined exercises in the gym with cardio and fitness, among which fitness exercises were the most common $(26 \%)$, as it was in the study by Gogojewicz et al. [30]. Female respondents' main goal was weight loss $(22 \%)$, better appearance and fitness improvement (16\%). World Health Organization recommends moderate practice of physical activity for at least 30 minutes a day, 5 days a week or intense practice of physical activity for at least 20 minutes a day, 3 days a week for people from 18 to 65 years old. Respondents have taken up physical activity with varied frequency during the week but within the limits set by WHO. Average number of hours of exercises per week within the study group was around 7. Single training session among women usually lasted from 1 to 1.5 hours and among men from 1.5 to 2 hours [17]. Study results indicate that respondents' motivation is high. Obtained results substantially exceeded the results of the study by Mazur et al. (2010), which stated that most women train 3 times a week. In the study by Wierzbicka (2012), the largest group (60\%) were women training twice a week. Respondents in this study were also asked about the knowledge of healthy nutrition rules and their compliance. Among most frequent answers about the source of dietary advice or dietary plans respondents indicated their trainer, similarly to the study by Adamczyk [29]. Respondents' awareness of healthy nutrition is high. Regular meals, proper intervals between them, appropriate fruit and vegetables supply as well as the amount of drunk liquids were the most frequent answers. Different study concerning nutrition habits of women attending fitness clubs (Mazur and colleagues 2010), in which 120 women from lubelskie and podkarpackie voivodeships were questioned, showed that those women had 4 regular meals a day $(54.1 \%)$ or 3 meals a day $(37.5 \%)$. Wierzbicka obtained a similar result in her 
study (2010) $-87 \%$ of respondents had 3 to 5 meals a day [31, 32]. High awareness of healthy nutrition rules (90\% of women and $74 \%$ of men) translates into compliance in slightly lower percentage $(82 \%$ of women and $68 \%$ of men). What is more, extensive information on the basis of the questionnaire concerning confectionery consumption shows that respondents do not comply with healthy nutrition rules. They admitted to the consumption of confectionery products despite regular physical activity and willingness to improve their body and health. Similar results were obtained in the Polish national study about the preferences of people concerning confectionery products. The study was carried out among a group of 1000 respondents. Survey indicates that majority of Poles (84\%) likes sweets and only $14 \%$ do not consume them due to the change to more active lifestyle. [33] Also in the study by Wierzbicka (2012) about the knowledge and nutrition habits of physically active women as much as $64 \%$ of those women admits to eating confectionery between meals [32]. Respondents of both sexes admitted to confectionery consumption every day. Wiza R, Gauer P. et al. achieved similar results in their study, which indicated that one third of the studied population included confectionery in their daily diet, $11 \%$ consumed them several times a day, $35 \%$ of respondents had to consume them several times a week [33]. Also in the study carried out by Grochowska et al. most of the respondents, both male and female, admitted to snacking sweets and pastry during the day [34]. This study shows that most of the female respondents (20\%) consume confectionery before dinner, men usually after dinner (22\%). Respondents with slightly less frequency consumed sweets after dinner $(12 \%$ of women), for teatime ( $16 \%$ of women and $14 \%$ of men) or before training ( $14 \%$ of men). One out of ten women admitted to eating sweets for breakfast and at night. Some of men admitted to eating confectionery products after breakfast $(8 \%)$, before dinner $(12 \%)$ and after their training (10\%). Results of this study are similar to the results of the study carried out on a group of students who mostly admitted - 92\% - to consuming sweets. Little difference concerns the percentage of young people at public universities $(93 \%)$ and private universities (90\%). The largest group of respondents were students consuming sweets every day (37\%). This study also included people who consumed confectionery every day (women - pastries (2\%), men - candy bars and chocolate (2\%)) [31]. Regular physical activity and the knowledge of healthy nutrition should have an effect on the respect of healthy lifestyle rules. This study has drawn the attention to the reasons concerning confectionery product consumption and thoughts and feelings of the respondents after the consumption of those products. All of women and $80 \%$ of men admitted that consuming confectionery products gives them pleasure. Respondents feel better due to confectionery consumption, experience energy boost and find sweets delicious. Respondents confessed to eating confectionery in front of the television set $(2 \%)$ or in company of others $(6 \%)$. The study by Maria Jeznach et al. (2010) carried out on a group of 1000 Polish citizens allowed separating confectionery consumer groups, two of which deserve special attention - "party people" (14.2\%) and "viewers" (10.1\%). As the names suggest, those groups consume sweets in social situations and in a domestic environment while watching television. Respondents of this study decided to cut down on confectionery consumption in relation to the amount of consumption from before taking up trainings, which started due to weight gain. Among women, weight gain varied between 1 and $2 \mathrm{~kg}$, among men up to $3 \mathrm{~kg}$. Our survey contains answers concerning weight gain of $10 \mathrm{~kg}(2 \%$ men and women), $15 \mathrm{~kg}$ ( $2 \%$ among women) or even $16 \mathrm{~kg}$ ( $2 \%$ among men). Half of the respondents feel remorse after consuming confectionery products and because of that majority of the respondents $(72 \%$ of women and $70 \%$ of men) have increased the amount of physical exercises. According to Zapolska et al., physical activity is one of the most important factors increasing chances for health improvement. The battle against obesity and overweight should be based on implementing the principles of rational nutrition, and physical activity can help in reducing progressive obesity and overweight of the Polish population [34]

\section{CONCLUSION}

People doing sports were aware of the side effects of sweets consumption and despite that they were frequently reaching for sweets. 2. Main reasons for taking up physical activity was willingness to improve body shape, fitness, muscle strength and for women it was weight loss. 3. Most of the respondents after taking up exercises decreased the consumption of confectionery products and improved their diet 


\section{REFERENCES}

1. Jarosz M.: Normy żywienia dla populacji polskiej nowelizacja. Instytut Żywności i Żywienia 2012. str. 29, 143-145, 154-158 2002,71,1434-145,154-158, 245-248.

2. Hasik J.,Gawęcki J. Żywienie człowieka zdrowego i chorego. Wydawnictwo Naukowe PWN, Warszawa 2000, 32-47.

3. Bean A. Żywienie w sporcie. Wydawnictwo ZYSK I SKA. Poznań 2013, 1537,103-114,173.

4. Celejowa I. Żywienie w sporcie, Wydawnictwo Lekarskie PZWL. Warszawa 2008, 31-39,103-114.

5. Seidler t. Mierzwa M. Szczuko M. Ocena sposobu żywienia osób uprawiających fitness - krótkie doniesienie, Med. Sport. 2010; 4(6); Vol. 26, 211-218.

6. Gawęcki J. (red.): Żywienie człowieka. Podstawy nauki o żywieniu. Wydawnictwo Naukowe PWN. Warszawa 2010., vol. 1., 11-26,129-133, 155200, 359.

7. Sekuła W., Niedziałek Z., Figurska K. Spożycie żywności w Polsce w latach 1950-1996 w przeliczeniu na energię i składniki odżywcze. Wyd IŻŻ, Warszawa 1997.

8. Biernat J., Żywienie, żywność a zdrowie, Wyd. Astrum, Wrocław 2001, 155.

9. Górski J., Fizjologiczne podstawy wysiłku fizycznego, Wydawnictwo Lekarskie PZWL, Warszawa 2008, 546548.

10. Marchewka A., Jungiewicz M., Aktywność fizyczna w młodości a jakość życia w starszym wieku, Gerontol Pol. 2008; 2 (16) 127-130.

11. Flaczyk E., Górecka D., Korczak J. Towaroznawstwo żywności pochodzenia roślinnego, Wdawnictwo Uniwerstetu Przyrodniczego w Poznaniu, Poznań 2011, 260-276.

12. Świderski F., Towaroznawstwo żywności przetworzonej z elementami technologii. Wyd.SGGW, Warszawa 2010, 495-498, 505.

13. Huang T.T., Harris K.J., Lee R.E., et al.: Assessing overweight, obesity, diet, and physical activity in college students. J. Am. Coll. Health, 2003; 52(2): 8386.

14. POL-HEALTH. Ministerstwo Zdrowia, Departament Polityki Zdrowotnej. Narodowy program zapobiegania nadzwadze i otyłości oraz przewklekłym chorobom niezakaźnym poprzez poprawę żywienia I aktywności fizycznej na lata 2007-2011. Warszawa 2009.

15. Giel K. Słodycze na cenzurowanym. Magazyn Stomatologiczny $\mathrm{nr}$ 1/200; 28.

16. Kłosiewicz-Latoszek L., Otyłość jako problem społeczny, zdrowotny i leczniczy, Probl Hig Epidemiol 2010; 91 (3) 339-343.

17. Recommended population levels of physical acitity for health, Global recommendations on physical activity for health, World Health Organization Geneva 2010, 15-34.
18. Jeznach M., Zegan M., Święcicka A., Henze A., Rogdaki E., Menrad K.: Stan i perspektywy rozwoju rynku żywności funkcjonalnej, Wyd. SGGW, Warszawa 2003.

19. Siró I., Kaplona E., Kaplona B., Lugasi S.: Functional food. Produkct development, marketing and consumer acceptance- a review, Apettite, 2008; 51:456-467.

20. Matissek R.: Susswaren - rechtliche Einordnunf und lebenmittelchchemische Bewertung. [w:] Stehe P., Matissek R.(red.): Ernahrung, Susswaren und Lebensstil. Verlag Dr. Koster, Berlin 2005; 4-13.

21. Stan zdrowia ludności Polski w 2004 r. GUS, Warszawa 2005.

22. Baryłko-Piekielna N., Jacórzyński B., Mielniczuk E., Pawlicka M., Daniewski M., Kostyra E.: Dzienne spożycie izomerów trans $\mathrm{w}$ polskiej racji pokarmowej. Żyw. Człow. Metab., 1998, 25,1,28-46.

23. Pijarowski E., Dłużewski M. , Dłużewska i wsp.: Ogólna Technologia Żywności. Wydawnictwo NaukowoTechniczne, Warszawa 1996.

24. Brawa S.: Odkryte tajemnice czekolady. Roczniki Warszawskiej Szkoły Zdrowia, Warszawa 2005, 80-88.

25. Makarewicz- Wujec M., Kozłowska-Wojciechowska M.: Apetyt na słodycze. www.resmedica.pl, z dn. 31.05.2010, 2008.

26. Sunram-Lea S.I., Foster J.K., Durlach P., Perez C.: Glucose facilitation of congnitive performance in healthy young adults: examination of the influence of fastduration, time of day and pre-consumption plasma glucose levels. Psychopharmacology, 2001; 157(1): 46-54.

27. Kopff B., Aktywność fizyczna w profilaktyce chorób cywilizacyjnych, Choroby społeczne i cywilizacyjne wybrane zagadnienia, Red. Bąk - Romaniszyn L., Uniwersytet Medyczny w Łodzi, Łódź 2013, 7-24.

28. Grochowska A., Kołpa M., Musiał Z., Wpływ otyłości na funkcjonowanie osób dorosłych, Probl Pieleg. 2010; 1 (1) 25-29.

29. Adamczyk J. G., Kowalki P., Boguszewski D., Ochwal A., Siewierski M. Podstawy Prozdrowotne u mężczyzn regularnie ćwiczących na siłowni. Warszawa 2012, 123-143.

30. Gogojewicz A., Kasprzak Z., Pilaczyńska-Szcześniak Ł.: Ocena sposobu odżywniania się kobiet aktywnych fizycznie w wieku 20-40 at. Bromat. Chem. Toksykol. XLV.2012, 3, 439-445.

31. Lisicki T. Żywienie przejawem stylu życia studentów ropoczynających studia. Rocznik PZH 2010, 61, Nr 3, Gdańsk, 283-287.

32. Wierzbicka I. Praca licencjacka pt. Wiedza i nawyki żywieniowe kobiet aktywnych fizycznie. Nysa 2012

33. Wiza R., Grauer P. i wsp. Rynek słodyczy w Polsce. KPMG w Polsce, Edycja 2014. kpmg.pl, 34-38. 
34. Grochowska A., Kopła M., Musiał Z. Wpływ otyłości na funkcjonowanie osób dorosłych. Problemy Pielęgniarstwa. 2010; 1(1): 25-29.

35. Zapolska J., Zarębska A., Ostrowska L. Fitness w leczeniu nadwagi i otyłości. Forum Zaburzeń Metabolicznych 2010, tom 1, nr 2, 100-105.
Address for correspondence:

\section{Grażyna Mierzwa}

Clinic of Vascular and Internal Diseases

Jan Biziel University Hospital No. 2

75 Ujejskiego Street

85-168 Bydgoszcz

Poland

tel./fax: +48523655105

e-mail: zpielgastro@cm.umk.pl

Received: 10.06.2016

Accepted for publication: 12.08.2016 